\title{
Study Resource Relationship
}

National Cancer Institute

\section{Source}

National Cancer Institute. Study Resource Relationship. NCI Thesaurus. Code C93471.

The association between a resource and the study on which it is used. 